\title{
Transference of Ethnobotanical Knowledge and Threat \& Conservation Status of Medicinal Plants in Ethiopia: Anthropological and Ethnobotanical Perspectives
}

\author{
Alemayehu Kefalew ${ }^{1 *}$ and Sara Sintayehu ${ }^{2}$ \\ ${ }^{1}$ Department of Plant Biology and Biodiversity Management, AddisAbaba University, Ethiopia \\ ${ }^{2}$ Department of Natural Resource Management, Haramaya University, Ethiopia
}

*Corresponding author: A Kefalew, Researcher of Ethnobotany, Department of Plant Biology and Biodiversity Management, Addis Ababa University, Addis Ababa, Ethiopia

Submission: 海 August 19, 2017; Published: 眥 October 10, 2017

\begin{abstract}
In Ethiopia, the use of traditional medicine for primary health care is becoming accepted and popular. However, it is under great risks when looked from the point of losing the knowledge transfer and the degradation of the vital medicinal plants. Thus, this review was initiated to briefly look into how is the very common way of transferring indigenous knowledge and to look at the threats \& conservation effort of medicinal plants in the country. The review indicates that indigenous knowledge of medicinal plants is transferred from a practitioner father to elder son as he is he is getting older. However, if there is no elder son it would be passed over to any one among the family who is supposed to be loyal to keep the knowledge secret; but if the practitioner does not have families, the knowledge passes to any one among his relatives who is believed to keep the knowledge secret. This review also showed that the main reasons for the degradation of medicinal plants in Ethiopia are environmental degradation, agricultural expansion, deforestation, over harvesting of species and invasive alien species. It is also indicated that Ethiopia is practicing both in-situ and ex-situ conservation. The Ethiopia traditional medicine association should work to fill the gap between how the herbalist can transfer their knowledge even to the wider researcher without compromising the rule to Convention on Biological Diversity (CBD). Participatory medicinal plant conservation shall be the best approach to follow in the country as a better conservation strategy. To access the conservation effort, the Ethiopian Biodiversity Institute (EBI) has to expand cold room gene banks and field gene banks in different provinces of the country.
\end{abstract}

Keywords: Ethiopia; Ethnobotanical knowledge; Ex-Situ conservation; Gene bank; Threats of medicinal plants

\section{Introduction}

Utilization of traditional medicinal plants in various areas of the world is very evident. It has been said that majority of the developing country is relied on traditional medicinal plants (TMPs) for the primary healthcare. This is not only because of poverty, shortage of allopathic doctors, and less access of hospitals but also due to the fact that it is more culturally accepted and does not produce complications for harming the physiology and anatomy of a patient as modern medicine may does [1,2]. While showing how far these TMs goes in line with our physiological needs, Hippocrates who mainly remembered as a father of medicine said that herbal remedies contain synergistic and/ or side effects neutralizing combinations [3].

Apart from the very reliance of developing countries on traditional medicines (TMs), and medicinal plants (MPs) the modern worlds are also showing great interests in using them for their healthcare. For example, India, Korea, Japan, China, and Malaysia are frequently cited countries in using traditional medicine. WHO [1] in its report noted that in Australia, Europe and North America, "complementary and alternative medicine" (CAM) is increasingly used in parallel to allopathic (orthodox) medicine, particularly for treating and managing chronic disease. The same report showed that $31 \%$ of the population in Belgium, $49 \%$ of the population in France and $70 \%$ of the population in Canada uses CAM at least once.

Report of the United Nations Conference on Trade and Development (UNCTAD) revealed that in United states of America ( USA) medicinal plants have been used as one alternative therapies and its application increased from 34\% in 1990 to $42 \%$ in 1997 [4]. In Latin America $71 \%$ of the population in Chile and $40 \%$ of population in Columbia have been reported to use TMs [5]. In many Asian countries TMs are widely used even though western medicines are often readily available [6,7]. 
Not only the indigenous people but also allopathic doctors are well aware of the use of TMs. For example, $40 \%$ of all general allopathic practitioners of United Kingdom (UK) offer some form of TM referral. In Germany $80 \%$ of the physicians prescribe herbals [3]. In Japan about $70-85 \%$ of physicians prescribe herbal medicine to their patients $[5,8]$.

The acceptability and use of TMPs in developed countries also revealed in terms of the high demand for the marketability of MPs for their theraptic values. Many developed countries like USA, Canada are involving in the exporting and/or importing TMPs. A report from WHO [1980] estimated the annual revenue generated from international trade of medicinal plants to have reached up to 500 million USD. Having understood the importance of traditional medicines some other developed countries like Australia, China, Mexico, Thailand, among many others, have started integrating TM/ CAM within their health care policies and programs [9].

As elsewhere in other continents, Africans have been supposed to use TMs to safe guard against disease since time immemorial $[10,11]$. The report from world health organization (WHO) revealed that about $80 \%$ of the population in Africa primarily relies on traditional medicinal plants [1]. As a matter of testimonial there has been found documentary evidences like that of medicinal plants of East Africa [12], Medicinal plants of North Africa [13]. Ayensu [13] have documented medicinal plants of West Africa. Hutching \& Terblanche [14] also emphasized the use of herbal remedies for the physical and physiological health care in South Africa.

WHO [1] reported the degree of some specific African countries towards the use of TMs; and accordingly $70 \%$ of the Benin people use TMs. Similarly $70 \%$ of Rwandans, $60 \%$ of Tanzanians, $60 \%$ of Uganda peoples are relied on TMs. The same organization in 2003 reported the use of TMs in treating and/or proactive prevention for some chronic disease. For example in Ghana, Mali, Nigeria and Zambia, the first line treatment for $60 \%$ of children with malaria is the use of herbal medicine, and in South Africa, 70\% of people living with HIV/AIDS use traditional medicine [15].

Ethiopia is a land of mosaic topographies which is responsible to have diverse Floras and Faunas [16]. It is also a land of multiple ethnic groups, and a land of Lucy (first known primitive human species; and scientifically known as Australopithecus Afarensis), Selam (Lucy's baby, world's oldest child belonging to the species Australopithecus Afarensis) and Ardi (Ardipithecus Ramidus which is another fossil that gave evolutionary proof for human origin and believed to have lived even before Lucy did on this world) [17]. These archeological findings signifies the country as the cradle of humanity; and hence it is not that much astonishing to have deep rooted indigenous cultures in Ethiopia. These traditional practices associated with plant base health care systems are in use since time immemorial [18] and is supposed to be the only system available for health care before the introduction of allopathic medicine to get cured from disease arising from worms, fungi, virus and protozoa [19]. According to this scholar $80 \%$ of the populations in Ethiopia use TMPs as the primarily health care system. As closer to this agreement WHO [1] reported that the number of Ethiopian populations using TMPs reached about 90\% exceeding other African countries like Benin (70\%), Rwanda (70\%),Tanzania $(60 \%)$, Uganda (60\%). This shows that using traditional medicine in Ethiopia for primary health care are becoming accepted and popular. In spite of the fact that TMP is a backbone of our medication system, it is under great risks from the point of losing the knowledge transfer about these traditions and the degradation of these vital medicinal plants. Thus, this review is initiated to briefly look into how is the very common way of transferring indigenous knowledge and to look at the threats \& conservation effort of medicinal plants in the country.

\section{Methods}

This review work was conducted by consulting relevant related literatures on transference of indigenous ethnobotanical knowledge and issues related to opportunities and challenges of ethnobotanical floras. Observation of Herbarium medicinal specimen, interview and personal communications with academicians and researchers on the area has also been undertaken.

\section{Significance of the Review}

This review paper is summarizing information on the transference and maintenance of ethnobotanical knowledge in Ethiopia where there is the imminent risk of loss of numerous floristic materials susceptible to ethnomedicinal use. This review is supposed to be used by academicians and researchers to imply a great advance in knowledge of both sociologist and ethnobotanist.

\section{Discussion on the Outcome of the Review}

\section{Most often priorities in transferringindigenous ethnobotanical knowledge in Ethiopia: anthropological perspectives}

Because Indigenous Knowledge (IK) is highly diverse and is with dynamic nature, it may not possible to develop a single and exclusive definition of the term. However, most scholars and organizations agreed that it is the knowledge, innovations, and practices which are an integral part of the culture, history and identity of a particular indigenous people and local communities around the world [19-25]. IK is broad term. For example, religion and spirituality for indigenous peoples are parts of IK [26,27]. It is not even confined to aborigines alone; all communities have developed their own body of knowledge over generations $[28,29]$.

Indigenous knowledge associated with medicinal plants has been part of the people's culture in Africa Sofowora [10]; and in Ethiopia more than $80 \%$ of the people are dependent on plants for their healthcare service [16]. In this country such healthcare system is often unwritten and handed down orally from generations to generations. The knowledge about the plant use and the method of preparation are often kept secret [30].

Most often the practitioner father, as he is getting older, gives priority to his elder son in passing over his IKs [31]. However, if there is no elder son it would be passed over to any one among the family who is supposed to be loyal to keep the knowledge 
secret; but if the practitioner does not have families, the knowledge passes to any one among his relatives who is believed to keep the knowledge secret [32].

Threats and conservation of medicinal plants in Ethiopia: ethnobotanical perspectives

Threat to medicinal plants in Ethiopia: In spite of the fact that TMPs and its associated IK have tremendous role in having medicinal value, food value, economic value, conservation value, etc. they are now under great threats mainly due to anthropogenic factors [33-35]. Those and many others studies also reported that most of the medicinal plants are from wild and only some others grow near home [36]. This tells us that the loss of forests directly links with the loss of MPs; but obviously forests are getting lost in Ethiopia. It has been said that about $16 \%$ of the country in 1954 was covered by forest which has gone down alarmingly to $4 \%$ in 1979 , and at present only less than $3 \%$ is supposed to be covered by forest [37]. More over Desta [38] claimed that the current rate of deforestation is about 150,000 to 200,000 hectares per year which is supposed to eliminate the remaining natural forests with in a period of thirty years.

A study conducted by Ensermu Kelbessa and his colleagues nearly two decades ago found out four important reasons for the degradation of medicinal plants and associated IK. These include environmental degradation, agricultural expansion, deforestation and over harvesting of species. In line with this a study conducted by Zemede [39] \& Edwards [40] also showed similar threatening factors exposing medicinal plants under a problem of sustainability and continuity. In addition to those findings recent studies by the International Livestock Research Institute (ILRI) and International Union for Conservation of Nature (IUCN) reported that invasive alien species are currently known treat to MPs in Ethiopia [41,42]. Very recent studies also indicated that some medicinal plants are under threat due to increased use pressure coupled with unsuitable harvesting that frequently targets roots and barks (Figure 1) for remedy preparations.

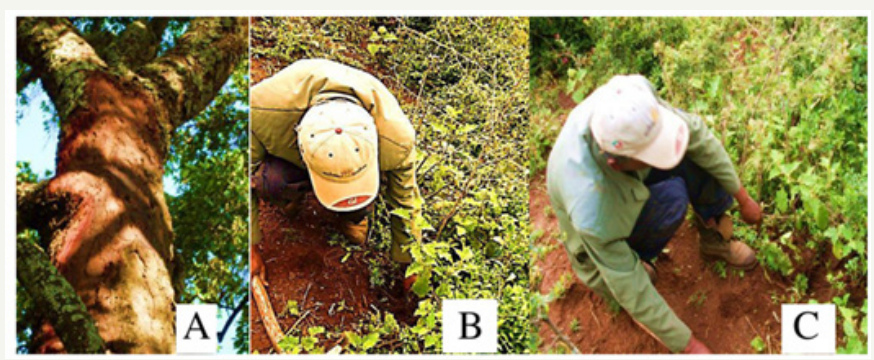

Figure 1: Examples of bad harvesting system, A-debarking Prunus africana \& B and C- uprooting of Asparagus africana for local remedial preparation in Ada'a District, Ethiopia.

The endangered threat status of Prunus africana throughout Ethiopia might have resulted from such practices. Taverniera abyssinica (commonly known as 'Dingetegna' in Amharic, the national language of Ethiopia) is also another important medicinal species in the country reported for treating stomach ache, headache and fever. The root part of this shrubis the most wanted and hunted part for herbal preparation; and consequently uprooting is killing this medicinal species making it one of the critically endangered species of the country [43]. Currently Taverniera abyssinica only found as a remnant of isolated and scattered populations in Shewa, Tigray and Welo regions of Ethiopia (Figure 2) [32,44].

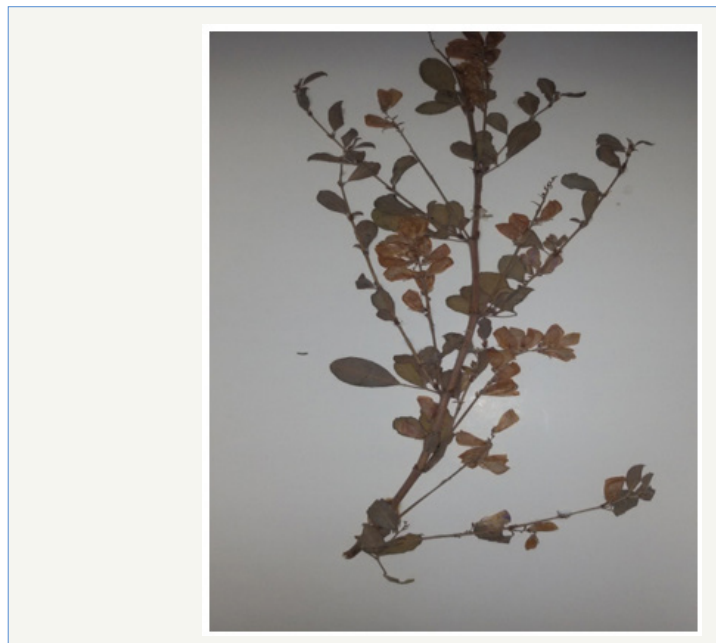

Figure 2: Taverniera Abyssinica, a well-known medicinal plants in Ethiopia and currently at risk due to over utilization of the root system for traditional remedy preparation (Photo taken with permission from Herbarium of Haramaya University, Ethiopia).

Those and other perilous events are exacerbating challenging pressure on medicinal plants of Ethiopia. Because of this degrading ongoing process, Tesfaye [45] seemingly scared and suggested that with the present ecological and socio-economical changes, the medicinal plants together with an ethnobotanical knowledge may be vanished from humanity forever, and this is a great disaster. That is why fully conscious ethnobotanists compare the death of an experienced herbalist to the loss of a whole library [9].

Conservation efforts of medicinal plants in Ethiopia: Efforts have been done for conservation of MPs in Ethiopia even though it is not yet enough when compared with the speed and frequency of taxa being lost. Both in-situ and ex-situ conservation approaches are being practicing by Ethiopian Biodiversity Institute (EBI).

The two forms of ex-situ conservation practicing by EBI are seed storage in Cold Room Gene Bank and Field Gene Bank; and accordingly around $31 \mathrm{MP}$ species were conserved in the cold room gene bank and around 300 samples of MPs were conserved in Wendo Genet Medicinal Field Gene Bank [45]. This scholar also gave notice about Community based in-situ conservation of MPs which are taking place in Kefa, Bale, Tigray, North Shewa, South Welo, and Eastern Shewa provinces of Ethiopia.

Ethiopia also signed the Convention on Biological Diversity (CBD) which contain article $8 \mathrm{j}$ to guaranty indigenous people to maintain and conserve their IK associated with medicinal plants [46]. About 1000 different medicinal plants have been conserved as a voucher specimen in the national herbarium of Ethiopia and data base has also been established for them [32]. Endeshaw [47] studied the ways to propagate some traditionally useful medicinal plants which is one important step for the conservation of medicinal 
plants by propagating in or near home gardens. Zemede Asfaw [24] also noted the contributions of Home gardens for the conservations of MPs. Whether aiming for conservation purpose or not Ethiopia, unlike many other countries both from Africa and Europe, do not have a legal trading of medicinal plants which by itself contribute to the conservation of MPs.

\section{Conclusion}

This review indicates that the knowledge about the plant use and the method of preparation in Ethiopia are often kept secret. In most cases the practitioner father, as he approaches to die, give priority to the elder son in passing over his IKs. However, if there is no elder son it would be passed over to any one among the family who is supposed to be loyal to keep the knowledge secret; but if the practitioner does not have families, the transference will be given to any one among his relatives who is believed to keep the knowledge secret. The main reasons for the degradation of medicinal plants and associated IK in Ethiopia are environmental degradation, agricultural expansion, deforestation, over harvesting of species and invasive alien species. The two forms of ex-situ conservation practicing by EBI are seed storage in Cold Room Gene Bank and Field Gene Bank; and accordingly around 31 MP species were conserved in the cold room gene bank and around 300 samples of MPs were conserved in Wendo Genet Medicinal Field Gene Bank.

\section{Recommendation}

The Ethiopia traditional medicine association should work strongly to convince the herbalists on how to transfer their knowledge even to the wider researcher without compromising the rule of CBD. Participatory medicinal plant conservation shall be the best approach to follow in the country as a better conservation strategy. To access the conservation effort, Ethiopian Biodiversity Institute (EBI) has to expand cold room gene banks and field gene banks in different provinces of the country.

\section{References}

1. WHO (2002) Traditional medicine: growing needs and potentials. World Health Organization, Geneva, pp. 1-6.

2. Hamilton AC, Pei Shengji, Kessy J, Khan AA, Logas-Witte S, et al. (2003) The purposes and teaching of applied ethnobotany. People and Plants working paper 11. WWF, Godalming, UK.

3. Gilani AH, Rahman AU (2005) Trends in ethno pharmacology. J Ethnopharmacol 100(1-2): 43-49.

4. UNCTAD (2000) Systems and national experiences for protecting traditional knowledge, innovations and practices, Geneva.

5. WHO (1999) Traditional, complementary and alternative medicines and therapies, World Health Organization, Geneva.

6. Velasquez J (2008) Indigenous knowledge for disaster risk reduction (ISDR): good practices and lessons learned from experiences in the Asian-pacific region.

7. Pei SJ (2001) Ethnobotanical approach of traditional medicine studies: some experiences from Asia, Kunming Institute of Botany. Pharm Biol 39(1): 74-79.

8. Elujoba AA, Odeleye OM Ogunyemi CM (2005) Traditional medicine development for medical and dental primary healthcare delivery system in Africa. Afr J Trad CAM 2(1): 46-61.
9. Balick MJ, Cox PAR (1996) Plants, people and culture. The Science of Ethnobotany. Scientific American Library, New York, USA.

10. Lewu FB, Afolayan AJ (2009) Ethnomedicine in South Africa: the role of weedy species. African Journal of Biotechnology 8(6): 929-934.

11. Izugbara CO, Duru ECJ (2008) Transethnic sojourns for ethnomedical knowledge among Igbo traditional healers in Nigeria: preliminary observations. Journal of World Anthropology: Occasional paper 2: 2.

12. Kokwaro JO (1976) Medicinal plants of East Africa, east african literature bureau, Nairobi, Kenya, pp. 223.

13. Boulos L (1983) Medicinal plants of North Africa. Reference publications, Inc., Algonac, Michigan, USA, pp. 286.

14. Hutching A, Terblanche SE (1989) Observation on the use of some known and suspected toxic liliiflorae in Zulu and Xhosa medicine. S Afr Med J 75(2): 62-69.

15. WHO (2003) Traditional medicine. Report by the secretariat, $56^{\text {th }}$ World health assembly, Provisional agenda item, World Health Organization, Geneva, 14.10, pp. 1-4.

16. Dawit Abebe and Ahadu Ayehu (1993) Medicinal plants and enigmatic health practice of north Ethiopia. Berehanina-Selam printing enterprise, Addis Ababa.

17. Kimbel WH, Delezene LK (2009) "Lucy" Redux: A review of research on Australopithecus afarensis. Am J Phys Anthropol 140(Suppl 49): 2-48.

18. Dawit Abebe (1998) Traditional medicine in Ethiopia: The attempts being made to promote it for effective and better utilization. SINET: Ethiopian Journal of Biological Science 9: 61-69.

19. Dawit Abebe (2001) The role of medicinal plants in health care coverage of Ethiopia, the possible integration. In: Medhin Zewdu, Abebe Demissie (Eds.), Proceedings of the national workshop on biodiversity conservation and sustainable use of medicinal plants in Ethiopia. IBCR, Addis Ababa, pp. 6-21.

20. FAO (1997) Non- Wood Forest Products. Medicinal Plants for forest conservation and health care. No. 11.

21. WHO (2000) Strategy for Traditional Medicine 2000-2003. WHO publication, Geneva.

22. Adam R (2002) Department of science and technology. Indigenous Knowledge Systems. Republic of South Africa.

23. Hareya Fassil (2003) Ethiopia: a qualitative understanding of local traditional knowledge and medicinal plant use. IK notes, 52: 1-4.

24. Zemede Asfaw (2001a) Home gardens in Ethiopia: Some observations and generalizations. In: Watson JW, Eyzaguirre PB, Eds.), Home gardens and in-situ conservation of plant genetic resources in farming systems. Proceedings of the second international home gardens workshop, Witzenhausen, Federal Republic of Germany, pp. 125-139.

25. Hawkins B (2008) Plants for life: medicinal plant conservation and botanic gardens. Botanic gardens conservation international, Richmond, UK.

26. Groenfeldt D (2003) Spirituality, worldview, and indigenous knowledge.

27. Berlin B, Berlin EA (2005) Some field methods in medical ethnobiology. Field Methods 17(3): 235-268.

28. Gorjestani N (2000) Indigenous knowledge for development: opportunities and Challenges, Geneva.

29. Thapa MB, Luintel YR, Gauchan B, Amatya K (2008) Indigenous knowledge on disaster mitigation: towards creating complimentarity between communities; and societies' knowledge. In: Shaw R, Uy N, Baumwoll J (Eds.), Indignous knowledge for disaster risk reduction: good practices and lessons learned from experiences in the Asian-pacific region. International Strategy for Disaster Reduction (ISDR), pp. 30-34.

30. Abbink J (1995) Medicinal and ritual plants for the Ethiopian southwest. An account of recent research. Indigenous Knowledge and Development Monitor 3(2): 6-8. 
31. Wilson RT, Gebremariam Wolde (1979) Medicine and magician Tigre: a contribution to the ethnobotany of the Ethiopian plateau. Economic Botany 33(1): 29-34.

32. Ensermu Kelbessa, Sebsebe Demissew, Zerihun Woldu, Edwards S (1992) Threatened endemic plans of Ethiopia. In: Edwards S, Zemede Asfaw (Eds.), Plants used in Africa traditional medicine as practiced in Ethiopia and Uganda. Addis Ababa University, Ethiopia, pp. 35-55.

33. Debela Hunde, Zemede Asefaw, Ensermu Kelbessa (2004) Use and management of ethenoveternary medicinal plants by indigenous people in " Boosat " Welenchiti Area Ethiopian. Journal of Biological Science 3(2): 113-132.

34. Mirutse Giday (2001) An ethnobotanical study of medicinal plants used by the Zay people in Ethiopia. CBK: s Skriftserie 3: 81-99.

35. Mirutse Giday (2007) Medicinal plants of the bench, meinit, and sheko ethinic groups in Ethiopia with emphasis on use diversity and distribution, PhD thesis, Addis Ababa University, Ethiopia.

36. Cunningham AB (2001) Applied ethnobotany: people, wild plants and use and conservation. Eartscan publisher limited, London.

37. Hedberg O (1979) Introduction to systematic botany, plant utilization and biosphere conservation, almgvist and eiksell, International, Stockholm, Sweden.

38. Desta Hamito (2001) Research methods in forestry: Principles and practices with particular references to Ethiopia. Larenstein University of Professional Education, Deventer, Netherlands.

39.Zemede Asfaw (2001b) The role of home gardens in production and conservation of medicinal plants. In: Medhin Zewdu and Abebe Demissie (Eds.), Proceedings of the national workshop on biodiversity conservation and sustainable use of medicinal plants held, pp. 76-91.
40. Edwards S (2001) The ecology and conservation status of medicinal plants in Ethiopia. What do we know? In: Medhin Zewdu and Abebe Demissie (Eds.), Proceeding of the national workshop on biodiversity conservation and sustainable use of medicinal plants in Ethiopia, pp. 46-55.

41. ILRI (2002) Impact of alien species on vegetation, soil and hydrology in a typical highland, International Livestock Research Institute (ILRI), Addis Ababa, Ethiopia.

42. IUCN (2004) Biodiversity loss caused by alien invasive species. IUCN, Gland, Switzerland.

43. Vivero JL, Ensermu Kelbessa, Sebsibe Demissew (2003) The red list of endemic trees \&shrubs of ethiopia and eritrea. fauna \& flora international, Cambridge, UK.

44. Fassil Kibebew, Getachew Addis (1996) Conservation and utilization of medicinal plants in Ethiopia. In: Abebe D (Ed.), Proceedings of the Workshop on Development and Utilization of Herbal Remedies in Ethiopia, EHNRI, Addis Ababa.

45. Tesfaye Awas (2003) Conservation of medicinal plants in Ethiopia. In: Urga Kelbessa, Asefa Ayele, Guta merge (Eds.), EHNRI. Addis Ababa, Ethiopia, pp. 99-107.

46. Fedral Negarit Gazeta (2006) A proclamation to provide for Access to genetic Resources and Community Knowledge and Community rights. Federal Democratic Republic of Ethiopia, Proclamation No.482/2006.

47. Endeshaw Bekele (2007) Study on actual situation of medicinal plants in Ethiopia. Prepared for JAICRF (Japan Association for International Collaboration of Agriculture and Forestry). 